\title{
OPTIMALISASI PROGRAM CSR DALAM MENJAGA KETAHANAN PANGAN MASA PANDEMI MELALUI SEDEKAH SAYUR HIDROPONIK
}

\author{
Alfian Abbasyah Harahap, Siti Fatonah, Aisyah Hadi Ramadani \\ Universitas Muhammadiyah Lamongan (UMLA) Jawa Timur, Indonesia \\ Email: alfian.harahap@pertamina.com,fatonah91@gmail.com, \\ aisyahramadani47@gmail.com
}

\begin{abstract}
Abstrak
Pandemi covid-19 telah berlangsung selama hampir 2 tahun yang diperkirakan akan menjadi krisis berkepanjangan yang berpotensi menimbulkan gagal pangan dan terjadi kelaparan yang meluas. Situasi ini dapat diselesaikan salah satunya dengan program ketahanan pangan. Perusahaan memiliki kewajiban social pada masyarakat di sekitar wilayah operasional dalam bentuk Corporate Social Responsibility (CSR). CSR diharapkan dapat berkontribusi dalam mengatasi krisis pangan masyarakat terdekat. Program ini bertujuan untuk mengevaluasi program hidroponik yang dicanangkan oleh PT Pertamina (Persero) DPPU Adi Sumarmo di wilayah operasional perusahaan dan menganalisis kebutuhan optimalisasi peran CSR dalam memaksimalkan dampak kebermanfaatan program. Program ini dilaksanakan di desa Tanjungsari, Ngemplak Boyolali dengan masyarakat sasaran kelompok pengurus masjid Tanjungsari, ibu-ibu jama'ah, dan pemuda masjid. Metode penggalian informasi dengan cara participatory rural appraisal (PRA). Program berhasil meresmikan Rumah Hidroponik Masithoh sebagai kelompok binaan perusahaan dan telah aktif melaksanakan kegiatan rutin bulanan dari menyemai bibit hingga panen sayur. Jenis sayur yang berhasil dikembangkan oleh kelompok meliputi selada, bayam hijau, kangkung, pakcoy, selada merah dan sawi dengan rata-rata persentase hasil panen terbanyak sayur kangkung (29,9\%). Kelompok Rumah Hidroponik Masithoh juga menjalankan inovasi sosial dalam bentuk "sedekah sayur" sebagai aksi solidaritas ketahanan pangan di tengah pandemic Covid-19. Optimalisasi peran CSR yang telah diterapkan oleh perusahaan dalam mendukung kelompok binaan antara lain sosialisasi, penyuluhan, pemberian bantuan modal dan fasilitas, pelatihan serta pendampingan.
\end{abstract}

Kata Kunci: hidroponik, pandemi covid-19; corporate social responsibility; ketahanan pangan; sedekah sayur

\section{Abstract}

The Covid-19 pandemic has lasted for almost 2 year's which is expected to become a prolonged crisis that has the potential to cause food failure and widespread hunger. One of the ways to solve this situation is through a food security program. The company has a social obligation to the community around its operational area in the form of Corporate Social Responsibility (CSR). CSR is expected to contribute in overcoming the food crisis of the nearest community. This program objectives to

$\begin{array}{ll}\text { How to cite: } & \text { Harahap, A. A., Fatonah, S., Ramadani, A. H., (2021) Pengaruh Brand Optimalisasi Program CSR } \\ & \text { dalam Menjaga Ketahanan Pangan Masa Pandemi Melalui Sedekah Sayur Hidroponik. Syntax Idea, } \\ & \text { 3(9), https://doi.org/10.36418/syntax-idea.v3i9.1483 } \\ \text { E-ISSN: } & \text { 2684-883X } \\ \text { Published by: } & \text { Ridwan Institute }\end{array}$


evaluate the hydroponic program launched by PT Pertamina (Persero) DPPU Adi Sumarmo in the company's operational area and analyze the need for optimizing the role of CSR in maximizing the impact of program benefits. This program was implemented in Tanjungsari village, Ngemplak Boyolali with the target community being the Tanjungsari mosque management group, congregational mothers, and mosque youth. The method of extracting information is by means of participatory rural appraisal (PRA). The program has succeeded in inaugurating Masithoh Hydroponic House as a company guided group and has been actively carrying out monthly routine activities from sowing seeds to harvesting vegetables. The types of vegetables that were successfully developed by the group included lettuce, green spinach, kale, pakcoy, red lettuce and mustard greens with the highest average yield of kale (29.9\%). The Masithoh Hydroponic House Group also carried out social innovations in the form of "sedekah sayur" as an act of solidarity for food security in the midst of the Covid-19 pandemic. Optimizing the role of CSR that has been implemented by the company in supporting the target groups, including socialization, counseling, providing capital and facilities assistance, training and mentoring.

Keywords: hydroponic; Covid-19 pandemic; corporate social responsibility; food security; vegetables alms

Received: 2021-08-22; Accepted: 2021-09-05; Published: 2021-09-20

\section{Pendahuluan}

Pandemi Covid-19 telah berlangsung selama hampir 2 tahun yang diperkirakan akan menimbulkan krisis berkepanjangan (Haryanto, 2020; Muhyiddin, 2020). Dampak yang terjadi tidak hanya terjadi pada sector kesehatan akan tetapi juga berimbas pada perekonomian (Nasution, et al., 2020), pariwisata (Sugihamretha, 2020), dan sosial kemasyarakatan (Purnama, et al., 2020). Diketahui bahwa penerapan berbagai upaya untuk mencegah penyebaran virus Covid-19 yang diberlakukan sebagai mandatory oleh pemerintah pusat seperti pembatasan social berskala besar (PSBB) dan pemberlakuan pembatasan kegiatan masyarakat (PPKM) memaksa sektor-sektor perdagangan mengalami penurunan produksi, terhambatnya jalur distribusi bahan pangan, dan beberapa negara serta wilayah memilih untuk mengamankan stok pangan di dalam wilayahnya dari pada mengirim ke luar wilayah. Kondisi yang terjadi berkembang menjadi defisit stok pangan local dan masional. Akibatnya terjadi fenomena panic buying di masyarakat. Fenomena ini kemudian mempengaruhi harga pasar, semakin langka ditemukan maka semakin tinggi harga pasar. Implikasi panjang dari fenomena tersebut adalah gagal pangan dan terjadi kelaparan yang meluas. Situasi ini dapat diselesaikan salah satunya dengan program ketahanan pangan. Hal ini diperkuat dengan himbauan menteri pertanian untuk mengembangakan ketahanan pangan yang berawal dari budidaya skala rumah tangga (Alamsyah, 2020) Bentuk urban farming menjadi alternative ketahanan pangan untuk memenuhi suplai akan sayuran dan buah secara mandiri. Teknik menanam urban farming yang mudah, efisien, dan cepat produksi yaitu hidroponik. Selain sebagai ketahanan pangan, hidroponik juga menciptakan iklim mikro 
perkotaan yang lebih sejuk (Tutuko et al., 2018). Hidroponik lebih unggul dari bertani secara konvensional dengan media tanah dengan kepadatan tanaman persatuan luas dapat dioptimalkan sehingga hemat lahan, mutu, produk, dan sterilitas terjamin karena penggunaan nutrient dipasok terkendali, serta tidak bergantung musim/waktu tanam dan panen sehingga dapat diatur sesuai kebutuhan (Tando, 2019).

Perusahaan memiliki kewajiban social pada masyarakat di sekitar wilayah operasional dalam bentuk Corporate Social Responsibility (CSR). CSR diharapkan dapat berkontribusi dalam mengatasi krisis pangan masyarakat terdekat. PT Pertamina (Persero) DPPU Adi Sumarmo pada tahun 2020 berinisiatif melakukan pendampingan kepada kelompok masyarakat dalam program ketahanan pangan dengan teknik hidroponik di wilayah Tanjungsari, Ngemplak, Boyolali. Penelitian terkait dengan program CSR perusahaan dengan program hidroponik juga dilaksanakan oleh Widayanti, (2020) yang membahas pengembangan hidroponik sebagai komoditas ekonomi dalam bentuk UMKM. Penelitian menngenai fungsi perusahaan dalam mendukung kegiatan hidroponik juga dilakukan oleh (Fikar, 2020) yang menganalisis peran dan fungsi humas perushaan dalam keberhasulan program CSR sehingga mampu membentuk agrowisata hidroponik. Dari kedua penelitian tersebut pembinaan CSR berfokus pada faktor ekonomi dari hidroponik sehingga kebermanfaatan program hanya dinikmati oleh kelompok sasaran tertentu. Pada masa pandemic ini, program CSR yang dicanangkan tidak hanya menguntungkan bagi segelintir personal kelompok namun diharapkan memiliki kebrmanfaatan yang lebih luas bagi masyarakat di luar kelompok sasaran. Untuk itu PT Pertamina DPPU Adi Sumarmo membina kelompok hidroponik dengan konsep inovasi social yaitu dengan sedekah sayur.

Pada tahap awal kelompok belum optimal menjalankan kegiatan hidroponik sehingga pada pendampingan berikutnya perlu adanya langkah optimalisasi implementasi CSR guna memperoleh kebermanfaatan yang lebih luas. Penelitian ini bertujuan untuk menganalisis pelaksanaan program serta merumuskan strategi optimalisasi CSR PT Pertamina DPPU Pattimura dalam menjaga ketahanan pangan masyarakat di sekitar wilayah operasional.

\section{Metode Penelitian}

Penelitian ini dilakukan menggunakan metode kualitatif yang berfokus pada studi kasus dan analisis fenomena sosial program CSR PT Pertamina DPPU Adi Sumarmo. Sasaran program ini yaitu pengurus, jama'ah, dan pemuda masjid dusun Tanjungsari, Desa Ngresep, Kecamatan Ngemplak, Kabupaten Boyolali yang berada di wilayah ring 1 PT Pertamina DPPU Adi Sumarmo. Kegiatan dilaksanakan dari bulan November 2020-Mei 2021.

Data penelitian diambil menggunakan teknik observasi lapangan dan wawancara serta didukung kajian teoritis dari penelitian terkait. Parameter penelitian yang diamati mengacu pada penelitian (Furtado et al., 2014) difokuskan pada tiga hal yaitu tahap pelaksanaan program, tanggapan dan tingkat partisipasi masyarakat sasaran program, dan analisis tingkat keberhasilan dan manfaat program serta tindak lanjut program. 
Observasi tahap pelaksanaan program dimulai dari aktivitas focus group discussion (FGD) antara stakeholder, kelompok sasaran dan pelaksana program, kemudian implementasi program, hingga evaluasi program dengan mempertanyakan seberapa jauh pelibatan masyarakat disetiap proses kegiatan baik dari aktivitas pemikiran, perencaan, pelaksanaa, pendampingan, dan evaluasi program (Hendrawati et al., 2018). Kegiatan berikutnya berupa sosialisasi, penyuluhan, pemberian bantuan modal dan fasilitas, serta pendampingan sebagai bentuk optimalisasi program CSR. Data tanggapan dan tingkat partisipasi masyarakat diambil setelah pelaksanaan kegiatan sosialisasi, penyuluhan, dan pemberian bantuan modal dan fasilitas serta pendampingan dengan instumen kuisioner dan wawancara. Tingkat keberhasilan, manfaat program program dianalisis dari indeepth interview dengan pendekatan purposive sampling pada kelompok sasaran yang terlibat, keseluruhan hasil pengmatan terhadap parameter selanjutnya digunakan sebagai referensi merusmuskan strategi tindak lanjut dan optimalisasi program CSR (Masiha, Habiba, Abbas, Saud, \& Ariadi, 2018).

\section{Hasil dan Pembahasan}

\section{Pelaksanaan Program Hidroponik CSR PT Pertamina DPPU Adi Sumarmo}

CSR PT Pertamina DPPU Adi Sumarmo berhasil meresmikan program Rumah Hidroponik Masithoh pada bulan November 2020. Peresmian ini menandakan komitment perusahaan dalam mendampingi kelompok sasaran dalam menjalankan program ketahanan pangan melalui hidroponik secara berkelanjutan. Capaian peresmian rumah hidroponik melalui proses focus group discussion (FGD) yang melibatkan pengurus masjid, ibu-ibu jama'ah, pemuda masjid dan pengurus desa setempat. FGD berhasil mengidentifikasi masalah dan memetakan keperluan kelompok sasaran dalam menjalankan hidroponik. FGD juga menyepakati pembentukan kelompok pengurus rumah hidroponik masitoh. Pengurus terdiri dari penasehat (ketua takmir masjid Tanjungsari), pengurus harian (ketua, sekretaris, bendahara), koordinator teknis, sie keamanan, dan anggota, jumlah keseluruhan pengurus 19 orang.

Setelah FGD, langkah selanjutnya adalah mengadakan sosialisasi konsep kegiatan ketahanan pangan dengan teknik hidroponik yang dilakukan oleh Rumah Hidroponik Masitoh kepada masyarakat di sekitar masjid. PT Pertamina DPPU Adi Sumarmo berperan serta dalam membuka jaringan kerjasama dengan stakeholder terkait seperti dengan pemerintah desa dan penyuluh pertanian terdekat. Kegiatan ini membantu penyuluhan mengenai teknik hidroponik yang baik dan benar kepada pengurus. Adapun sistem hidroponik yang digunakan oleh Rumah Hidroponik Masitoh yaitu Ebb and flow system. Penyuluh pertanian setempat memberikan demonstrasi perakitan system hidroponik, penyemaian benih, penanaman, dan pemanenan hasil hidroponik. 


\section{Tanggapan Dan Tingkat Partisipasi Masyarakat Sasaran Program}

Inisiasi ketahanan pangan ini disambut antusias oleh kelompok dimana mereka tercatat sangat aktif melakukan kegiatan setiap bulan dan memiliki catatan kegiatan yang rapi. Catatan kegiatan perbulan tercantum pada tabel 1 .

Tabel 1

Catatan kegiatan bulanan Rumah Hidroponik Masitoh

\begin{tabular}{|c|c|}
\hline Waktu & Kegiatan Rutin \\
\hline Oktober - November 2020 & $\begin{array}{l}\text { 1. Semai benih selada, bayam bijau, kangkung, } \\
\text { pakcoy, selada merah } \\
\text { 2. Panen selada, bayam hijau, kangkung, pakcoy, } \\
\text { selada merah }\end{array}$ \\
\hline November - Dese & $\begin{array}{l}\text { 1. Semai benih selada, bayam bijau, kangkung, } \\
\text { pakcoy } \\
\text { 2. Panen selada, bayam hijau, kangkung, pakcoy }\end{array}$ \\
\hline Januari - Maret 2021 & $\begin{array}{l}\text { 1. Semai benih selada, bayam bijau, kangkung, sawi } \\
\text { 2. Panen selada, bayam hijau, kangkung, sawi }\end{array}$ \\
\hline Maret - April 2021 & $\begin{array}{l}\text { 1. Semai benih selada, bayam bijau, kangkung, sawi } \\
\text { 2. Panen selada, bayam hijau, kangkung, sawi }\end{array}$ \\
\hline April - Mei 2021 & $\begin{array}{l}\text { 1. Semai benih selada, bayam bijau, kangkung } \\
\text { 2. Panen selada, bayam hijau, kangkung }\end{array}$ \\
\hline
\end{tabular}

Sumber: Data primer penelitian

Partisipasi kelompok yang tinggi menjadi pertimbangan bagi perusahaan untuk melanjutkan program secara terus menerus dan dikembangkan untuk lebih professional. Untuk itu CSR perusahaan memberikan bantuan modal fasilitas sarana prasarana kepada Rumah Hidroponik Masitoh agar kegiatan berlanjut secara efektif dan maksimal yaitu berupa bangunan rumah hidroponik, pagar, media tanam hidroponik (rockwoll), benih sayuran, net pot, kain flannel untuk penyemaian, alat pH dan TDS meter, serta modul teknis hidroponik.

\section{Tingkat Keberhasilan, Manfaat dan Tindak Lanjut Program}

Data hasil panen sayur hidroponik yang dilakukan oleh kelompok Rumah Hidroponik Masitoh perbulan ditampilkan pada tabel 2. Hasil menunjukkan bahwa panen tiap jenis sayuran berbeda-beda. Di Rumah Hidroponik Masitoh, kangkung menjadi sayur dengan presentasi panen terbanyak $(29,9 \%)$ dan sawi menunjukkan hasil paling sedikit $(20,4 \%)$. Persentase panen memperlihatkan keberhasilan jenis sayur yang ditanam untuk tumbuh dengan baik pada cara tanam hidroponik. Tingkat keberhasilan panen kangkung yang tinggi pada kegiatan ini senada dengan hasil yang diperoleh oleh (Moerhasrianto, 2011) dimana dalam penelitiannya kangkung memiliki laju pertumbuhan paling baik dibanding sawi daging dan sawi hijau pada media hidroponik. Sawi memang kurang cocok ditumbuhkan di media cair, pertumbuhan sawi jauh lebih baik pada media padat seperti tanah karena sawi memiliki perakaran yang kurang adaptif dengan kondisi selalu tergenang (Setiawan, Ginting, \& Karyanto, 2013). 
Tabel 2

Persentase Hasil Panen Sayuran Rumah Hidroponik Masitoh

\begin{tabular}{|c|c|c|c|c|c|}
\hline \multirow[t]{2}{*}{ Jenis Sayuran } & \multicolumn{4}{|c|}{ Persentase Hasil Panen } & \multirow[t]{2}{*}{$\begin{array}{c}\text { Rata- } \\
\text { rata }\end{array}$} \\
\hline & Nov-20 & Dec-20 & Mar-21 & Apr-21 & \\
\hline selada & 26,7 & 24,3 & 26,7 & 30 & 26,9 \\
\hline bayam hijau & 23,3 & 16,8 & 18 & 34 & 23,0 \\
\hline kangkung & 32 & 23,3 & 20 & 44,4 & 29,9 \\
\hline pakcoy & 20 & 26,7 & - & - & 23,3 \\
\hline selada merah & 25 & - & - & - & 25,0 \\
\hline sawi & - & - & 20,8 & 20 & 20,4 \\
\hline
\end{tabular}

Sumber: Data primer penelitian

Secara umum, hasil panen sayur Rumah Hidroponik Masitoh masih kurang optimal $(<50 \%)$. Untuk itu diperlukan upaya-upaya untuk meningkatkan hasil panen tersebut. Kendala yang dihadapi oleh kelompok terkait dengan rendahnya hasil panen adalah kurangnya pengetahuan pengurus terhadap cara merawat tanaman. Kendala ini lah yang kemudian ditindaklanjuti oleh PT Pertamina (Persero) DPPU Adi Sumarmo akan diatasi dengan mengoptimalkan implementasi program CSR nya berupa pelatihan penguatan skill pengurus dalam teknik hidroponik, pendampingan perawatan, serta support penambahan bibit dan nutrisi. Program pendampingan sangat diperlukan oleh masyarakat mitra dan perusahaan, dimana tujuan pendampingan untuk memastikan bahwa program dapat berjalan sesuai harapan (Mujriati, Nafisah, Hayatunnisa, \& Japa, 2021). Pendampingan yang efektif dan efisien dalam bentuk tatap muka langsung antara pendamping (penyuluh pertanian, perusahaan) dan kelompok. Tatap muka langsung memungkinkan kelompok dapat terlibat dan melihat langsung proses pembuatan alat, pembibitan, dan pembuatan pupuk organik cair untuk hidroponik.

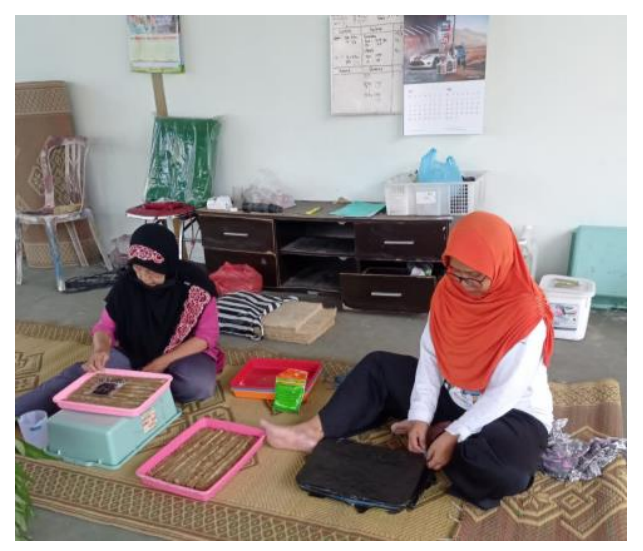

Gambar 1

Aktivitas menyemai benih sayur 


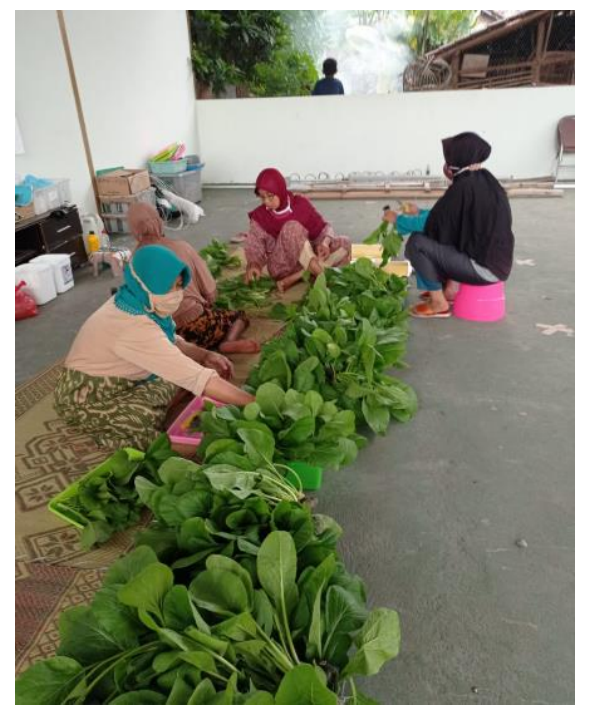

Gambar 2

Aktifitas pemanenan

Hasil panen hidroponik berupa selada, bayam hijau, kangkung, pakcoy, selada merah dan sawi kemudian dibagikan secara sukarela kepada penduduk Tanjungsari dengan konsep "sedekah sayur" dengan tagline kegiatan "ambil secukupnya bayar seikhlasnya" dimana warga yang membeli sayur dapat mengambil sesuai yang dibutuhkan dan membayar semampu kondisi keuangan mereka. Konsep ini mengedepankan kepercayaan sosial dan kerelaan membantu dalam misi kemanusiaan. Di tengah masa pandemic Covid-19, konsep semacam ini sangat dibutuhkan oleh masyarakat terdampak dan memberikan manfaat yang luas. Konsep sedekah sayur disambut baik oleh warga Tanjungsari. Umpan balik warga penerima manfaat Rumah Hidroponik Masitoh antara lain peningkatan jumlah jama'ah masjid Tanjungsari, meningkatnya budaya gotong royong, dan meningkatnya kepedulian sosial.

Bentuk gotong royong semacam ini bisa jadi merupakan salah satu aksi implementasi program jogo tonggo yang digencarkan oleh pemerintah Jawa Tengah untuk memperkuat ketahanan pangan, kesehatan, dan perekonomian warga selama pandemi Covid-19 di tingkat desa yang merupakan warisan kearifan lokal setempat (Probosiwi \& Putri, 2021) (Arditama \& Lestari, 2020). Program ini meningkatkan fungsi sosial masyarakat sebagai bagian dari lingkungannya dengan membantu orang lain. Dengan program sedekah sayur dan jogo tonggo masyarakat yang tidak mampu dibantu untuk tetap memperoleh hak dasar kehidupannya.

Inovasi sosial dalam bentuk sedekah sayur yang telah diterapkan oleh kelompok ini menjadi peluang bagi perusahaan untuk lebih menujukkan dukungannya. Salah satu yang dapat diberikan adalah memberikan sentuhan teknologi untuk program sedekah sayur, sehingga masyarakat yang membutuhkan dapat dengan cepat memperoleh informasi ketersediaan sayur dan jangkauan dampak manfaat dapat lebih luas. Selain itu, konsep sedekah sayur masih dapat dikembangkan kearah kewirausahaan sosial. 


\section{Kesimpulan}

Program CSR PT Pertamina (Persero) DPPU Adi Sumarmo telah berhasil meresmikan Rumah Hidroponik Masithoh yang berada di desa Tanjungsari, Ngemplak Boyolali yang berada di Ring 1 wilayah operasional perusahaan sebagai kelompok binaan. Kelompok binaan telah aktif mendukung program hidroponik dan telah menghasilkan panen sayur serta menerapkan konsep Sedekah Sayur sebagai bentuk ketahanan pangan selama pandemic covid-19, namun diperlukan optimalisasi peran CSR dalam memaksimalkan hasil hidroponik kelompok dan mengurai kendala yang dialami. Optimalisasi CSR yang telah dilakukan meliputi sosialisasi, penyuluhan, pemberian bantuan modal dan fasilitas, pelatihan serta pendampingan. Konsep sedakah sayur memiliki prospek dikembangkan sebagai model kewirausahaan social dengan produk unggulan berbagai sayuran hidroponik yang telah tersertifikasi. 


\section{BIBLIOGRAFI}

Alamsyah, I. .. (2020). Mentan SYL: Perkuat Ketahanan Pangan Berawal dari Rumah (online). Retrieved from https://www.republika.co.id/berita/qlo9a8349/mentan-sylperkuat-ketahanan-pangan-berawal-dari-rumah.

Arditama, Erisandi, \& Lestari, Puji. (2020). Jogo Tonggo : Membangkitkan Kesadaran Dan Ketaatan Warga Berbasis Kearifan Lokal Pada Masa Pandemi Covid-19 Di Jawa Tengah. Jurnal Pendidikan Undiksha, 8(2), 157-167. Google Scholar

Fikar, Muhammad Qarel. (2020). Analisis fungsi dan peran humas dalam program csr pt. pembangkit jawa bali unit bisnis jasa operasi dan maintenance pltmg arun dalam meningkatkan citra perusahaan. Skripsi Universitas Islam Indonesia Yogyakarta. Google Scholar

Furtado, Milena B., Costa, Mauro W., Pranoto, Edward A., Salimova, Ekaterina, Pinto, Alexander R., Lam, Nicholas T., Park, Anthony, Snider, Paige, Chandran, Anjana, \& Harvey, Richard P. (2014). Cardiogenic genes expressed in cardiac fibroblasts contribute to heart development and repair. Circulation Research, 114(9), 14221434. Google Scholar

Haryanto. (2020). Dampak Covid-19 terhadap Pergerakan Nilai Tukar Rupiah dan Indeks Harga Saham Gabungan (IHSG). Jurnal Perencanaan Pembangunan: The Indonesian Journal of Development Planning, 4(2), 151-165. Google Scholar

Hendrawati, Sri, Mardhiyah, Ai, Mediani, Henny Suzana, Nurhidayah, Ikeu, Mardiah, Wiwi, Adistie, Fanny, \& Maryam, Nenden Nur Asriyani. (2018). Pemberdayaan Kader Posyandu dalam Stimulasi Deteksi dan Intervensi Dini Tumbuh Kembang (SDIDTK) pada Anak Usia 0-6 Tahun di Desa Cileles Kecamatan Jatinangor Kabupaten Sumedang. Media Karya Kesehatan, 1(1). Google Scholar

Masiha, S., Habiba, U., Abbas, Z., Saud, M., \& Ariadi, S. (2018). Exploring the link between the use of facebook and political participation among youth in Pakistan. Journal of Political Sciences \& Public Affairs, 6(1), 1-7. Google Scholar

Moerhasrianto, Pradyto. (2011). Respon pertumbuhan tiga macam sayuran pada berbagai konsentrasi nutrisi larutan hidroponik. Google Scholar

Muhyiddin. (2020). Covid-19, New Normal, dan Perencanaan Pembangunan di Indonesia. Jurnal Perencanaan Pembangunan: The Indonesian Journal of Development Planning, 4(2), 240-252. Google Scholar

Mujriati, Annisa, Nafisah, Khairatun, Hayatunnisa, Khusnul, \& Japa, Lalu. (2021). Pelatihan Budidaya Sayuran Hidroponik Menggunakan Sistem Wicks Sebagai Usaha Pemberdayaan Masyarakat di Desa Cenggu. Jurnal Pengabdian Magister Pendidikan IPA, 4(2). Google Scholar

Nasution, Dito Aditia Darma, Erlina, Erlina, \& Muda, Iskandar. (2020). Dampak 
Pandemi COVID-19 terhadap Perekonomian Indonesia. Jurnal Benefita, 5(2), 212. Google Scholar

Probosiwi, Ratih, \& Putri, Afrinia Lisditya. (2021). Jogo Tonggo: Solidaritas Masyarakat di Era Pandemi Covid-19. Sosio Konsepsia, 10(2), 177-192. Google Scholar

Purnama, Desca Thea, Juliansyah, Viza, \& Chainar. (2020). Covid-19 Pandemic , Social Changes and Its Consequences in Society. Proyeksi: Jurnal Ilmu Sosial Dan Humaniora, 25(1), 1-13.

Setiawan, Nanang, Ginting, Yohannes Cahya, \& Karyanto, Agus. (2013). Respons Sawi (Brassica Juncea L. Czern) Yang Dibudidayakan Secara Hidroponik Pada Media Padat Dan Cair Terhadap Konsentrasi Nitrogen. Jurnal Agrotek Tropika, 1(3). Google Scholar

Sugihamretha, I. Dewa Gde. (2020). Respon Kebijakan: Mitigasi Dampak Wabah Covid-19 Pada Sektor Pariwisata. Jurnal Perencanaan Pembangunan: The Indonesian Journal of Development Planning, 4(2), 191-206. Google Scholar

Tando, Edi. (2019). Pemanfaatan Teknologi Greenhouse dan Hidroponik Sebagai Solusi Menghadapi Perubahan Iklim Dalam Budidaya Tanaman Hortikultura. Buana Sains, 19(1), 91-102. Google Scholar

Tutuko, Pindo, Widiyaningtyas, Triyanna, Sonalitha, Elta, \& Nurdewanto, Bambang. (2018). Pemberdayaan kelompok rumah pangan lestari dalam budidaya tanaman hidroponik. JAPI (Jurnal Akses Pengabdian Indonesia), 3(1), 7-16. Google Scholar

Widayanti, Tri. (2020). Peran Corporate Social Responsibility (Csr) Pt Pelindo Iii Dalam Peningkatan Pendapatan Masyarakat Melalui Kampung Binaan Hidroponik Di Simokalangan Rt 8 Surabaya. Skripsi. Uinersitas Islam Negeri Sunan Kalijaga Yogyakarta.

\section{Copyright holder:}

Alfian Abbasyah Harahap, Siti Fatonah, Aisyah Hadi Ramadani (2021)

\section{First publication right:}

Syntax Idea

This article is licensed under: 